\title{
Kuršių nerijos nacionalinio parko paveldo būklès vertinimas
}

\section{Ligita Braškytė,}

\section{Regina Prapiestienè}

Vilniaus universitetas, M. K. Čiurlionio g. 27, 03101 Vilnius

El.paštas: ligita.braskyte@gf.stud.vu.lt; regina.prapiestiene@gf.vu.lt
Braškytė L., Prapiestienė R. Kuršių nerijos nacionalinio parko paveldo būklès vertinimas. Geologija. Geografija. 2018. T. 4(1). ISSN 2351-7549.

Straipsnyje, remiantis natūrinių stebèjimų metu surinktais duomenimis, pateikta kompleksinès Kuršių nerijos nacionalinio parko paveldo būklès analizė. Visapusiškam paveldo būklès ištirtumui užtikrinti, ịvertinta atskirų gamtos ir kultūros paveldo objektų dabartinè situacija, palyginta su skirtingų metų kultūros paveldo objektų būklès duomenimis. Nustatyta, kad dviejų iš 11 gamtos paveldo objektų situacija nuolatos blogèja, o $24 \%$ kultūros paveldo objektų padètis šiuo metu yra pablogèjusi. Remiantis paveldo objektų būklès duomenimis, išskirti trys probleminiai arealai, kurie mažina tarptautiniu mastu saugomo kultūrinio kraštovaizdžio paveldo vertę. Pagrindinès priežastys, lemiančios Kuršiu nerijos nacionalinio parko paveldo būklès blogèjimą, - nuolatinès stebèsenos nevykdymas, tarpinstitucinio bendradarbiavimo trūkumas, rekreacinè digresija, teisinio apsaugos statuso nepakankamumas. Kompleksinio pobūdžio paveldo būklès tyrimai saugomose teritorijose yra reikšmingi teoriniu aspektu - renkant duomenis apie atskirų paveldo objektų būklę; praktiniu aspektu - formuojant prioritetines paveldo tvarkybos kryptis ir teikiant pasiūlymus tvarkymo planų zonų ribų korekcijoms.

Raktažodžiai: gamtos paveldas, kultūros paveldas, kultūrinis kraštovaizdis, paveldo būklè

\section{IVADAS}

Paveldas - žmogaus, tautos ir valstybès turtas, atspindintis istoriją, kultūrą, formuojantis šalies gamtinį ir kultūrinị identitetą. Paveldo vertę turintys objektai ir vietovès privalo būti puoselèjami, saugomi, o jų būsenai skiriamas didžiulis dèmesys. Lietuvoje, siekiant užtikrinti gerą paveldo būklę, steigiamos kompleksinès saugomos teritorijos - nacionaliniai ir regioniniai parkai, kurie ịkurti gamtiniu ir kultūriniu požiūriu pačiose vertingiausiose Lietuvos teritorijose (Saugomu teritoriju istatymas, 2001). Vertingiausios paveldo vietovès, pasižyminčios unikaliu gamtos ir kultūros paveldu, taip pat gali būti ịtraukiamos i UNESCO pasaulio paveldo sąrašą. Viena iš tokių Lietuvoje esančių teritorijų - Kuršių nerijos nacionalinis parkas, kuris kartu su Rusijos Federacijos teritorijoje esančiu Kurshskaya kosa nacionaliniu parku paskelbtas saugomu kultūriniu kraštovaizdžiu (24COM XC.1 - Curonian Spit..., 2000). Tarptautinis Kuršių nerijos nacionalinio parko apsaugos statusas įrodo šios vietovès ir jos paveldo išskirtinę visuotinę vertę, todèl kompleksiniai paveldo būklès tyrimai yra itin svarbūs.

Nacionalinès saugomos teritorijos statusas Kuršių nerijai suteiktas 1992 m., o tarptautini statusą nerija igavo tik $2000 \mathrm{~m}$., tačiau ja ir jos 
išskirtine aplinka susidomèta kur kas anksčiau. Iki nepriklausomybès atkūrimo su Kuršiu nerija susiję tyrimai daugiausia orientuoti $\mathfrak{x}$ vieną iš šios teritorijos komponentų: kraštovaizdi ar sudedamąsias jo dalis, atskiras paveldo rūšis ar pavienius gamtinius komponentus. Jau XX a. šeštajame dešimtmetyje Kuršių nerija pradejo domètis H. Kristapavičius ir J. Meškys. Autoriai daugiausia rašè apie paveldo vertę turinčius užpustytus Kuršių nerijos kaimus (Kristapavičius, 1957; Meškys, 1957). Kuršių nerijos kraštovaizdžiui ir archeologinèms vertybėms daug dèmesio skyrè V. Gudelis (1960, 1970, 1997). Labiausiai augalija ir kopomis domejosi ir jas tyrè V. Telksnytè (1979). Augalijai ir jos pobūdžiui bei kraštovaizdžiui neabejinga buvo R. Bandžiulienè (Bandžiulienè ir kt., 1983).

Po nepriklausomybès atgavimo atsirado vis daugiau literatūros, kurioje Kuršių nerija pristatoma ar nagrinėjama kaip kompleksinio pobūdžio Lietuvos saugoma teritorija. J. Aukštaitis ir J. Bučas - tai pirmieji autoriai, gana plačiai aptariantys Kuršių nerijos gamtinius ir kultūrinius kompleksus, jų sudedamąsias dalis. J. Bučas taip pat akcentuoja tarptautini nerijos statusą, nagrinejja ne tik kraštovaizdžio, bet ir paveldo ypatybes (Aukštaitis, 1996; Bučas, 2001). Taikomuoju požiūriu labai svarbūs P. Kavaliausko darbai. Profesorius prisidejo prie Kuršių nerijos nacionalinio parko tvarkymo plano, Kuršių nerijos nacionalinio parko ir jo zonų ribų plano sudarymo (Dèl Kuršių..., 2010; 2012), kurie tapo pamatiniais dokumentais siekiant užtikrinti racionalų šios teritorijos naudojimą, vertybių apsaugą ir tvarkymą.

Kuršių neriją tyrè ịvairų sričių mokslininkai. Jie domejosi įvairiomis šio krašto ypatybèmis: tirta nerijos geologiniai ir geomorfologiniai procesai, kopos, rekreacija ir turizmas, augalija, gaisrai ir jų padariniai, archeologinès vertybès, gyvenvietès, tačiau nuo XVI iki XXI a. daugiausia tirti pavieniai šios teritorijos gamtiniai ar kultūriniai elementai, o kompleksinio pobūdžio tyrimų atlikta itin mažai. Ypač stokojama kompleksinio pobūdžio darbų, kuriuose būtų nustatoma šios teritorijos paveldo vertė atsižvelgiant $\mathfrak{i}$ gamtos, kultūros paveldo objektus, kultūrinị kraštovaizdị kaip ì bendrą ir nedalomą visumą. Lietuvoje kultūrinis kraštovaizdis ir paveldas iprastai yra laikomi skirtingomis tyrimų kryptimis, tačiau kai kalbame apie Kuršių nerijos nacionalinị parką - toks požiūris būtų klaida.
Detalesnè su tyrimo tema susijusios literatūros analizè šiame straipsnyje nebus pateikta, nes išsami literatūros apžvalga jau buvo pristatyta ankstesniuose darbuose (Braškytė, 2017), šiame straipsnyje stengiamasi akcentuoti atlikto tyrimo rezultatus.

Kompleksiniai Kuršių nerijos nacionalinio parko paveldo būklès tyrimai yra labai svarbūs teoriškai - renkant duomenis apie atskirų paveldo objektų būklę; praktiškai - formuojant prioritetines paveldo tvarkybos kryptis ar teikiant pasiūlymus nacionalinio parko tvarkymo plano zonų ribų korekcijoms. Atlikto tyrimo rezultatai yra itin aktualūs, kadangi artimiausiu metu bus pradètas rengti naujas Kuršių nerijos nacionalinio parko tvarkymo planas.

\section{DARBO METODIKA}

Dèl nacionalinio ir tarptautinio Kuršių nerijos apsaugos statuso nacionalinio parko paveldo būklès vertinimas atliktas remiantis dviem pagrindiniais aspektais:

- Kuršių nerija yra nacionalinès reikšmès saugoma teritorija, reprezentuojanti Kuršiu nerijos etnokultūrinès srities (Lietuvos kraštovaizdžio etnokultūrinis..., 2008) gamtini ir kultūrinị kraštovaizdị, kurị atspindi parko teritorijoje esančios gamtos bei kultūros paveldo vertybès;

- Kuršių nerija yra pripažinta tarptautinès svarbos kultūriniu kraštovaizdžiu, kuris itrauktas i UNESCO pasaulio paveldo sąrašą kaip kultūros paveldo vertybè. Tai reiškia, kad visa Kuršių nerijos nacionalinio parko sausumos teritorija bus laikoma paveldo objektu.

Atliktas kompleksinis paveldo būklès tyrimas apėmè atskirų gamtos, kultūros paveldo objektų ir paveldo vertę turinčio kultūrinio kraštovaizdžio būklès vertinimą.

Pirmajame tyrimo etape vertinta gamtos paveldo objektų būklè. Remiantis Lietuvos Respublikos saugomų teritorijų valstybès kadastro duomenimis, pirmiausia apdoroti su gamtos paveldu susiję statistiniai duomenys, apibūdinta paveldo struktūra. Naudojantis nacionalinio parko direkcijos veiklos ataskaitomis, nustatytas gamtos paveldo objektų būklès pokytis 2009-2011 metais. Surinkus duomenis apie ankstesnę paveldo padètí, natūrinès fiksacijos metu ìvertinta esama 
gamtos paveldo objektų būklè, ji palyginta su 2009-2011 m. duomenimis.

Antrajame tyrimo etape vertinta kultūros paveldo objektu situacija. Remiantis Lietuvos Respublikos kultūros vertybių registro duomenimis, apdoroti su paveldu susiję statistiniai duomenys, nustatytos vyraujančios paveldo rūšys, apsaugos lygmuo, vertingųjų savybių pobūdis, procentinè visų paveldo objektų dalis. Atlikus statistinę paveldo analizę, natūrinès fiksacijos metu ịvertinta dabartinè kultūros paveldo objektų būklè. 2017 m. gegužès $3 \mathrm{~d}$. atliekant stebėseną buvo pildomi ne tik apžiūros aktai, bet ir atlikta kiekvieno objekto fotofiksacija (Braškytè, 2017). Būklè vertinta remiantis Lietuvos Respublikos kultūros ministro patvirtinta kultūros paveldo objektų būklès tikrinimo taisyklèse nurodyta metodologija. Kultūros paveldo objektai buvo vertinami penkių balų sistemoje (žr. 1 lentelę) (Dèl Kultūros paveldo objekto būklès..., 2005). Esama objektų būklè nustatyta palyginus per $2017 \mathrm{~m}$. natūrinius stebèjimus užfiksuotą paveldo būklę su kultūros vertybių registre pateiktomis objektų nuotraukomis, darytomis 2010-2012 metais. Pasirinktas toks tyrimo metodas, nes registre esančios nuotraukos yra vienintelis ịrodymas, liudijantis ankstesnę kultūros paveldo būklę. Iš stebėsenos metu gautų rezultatų sudaryta duomenų bazè, kurioje yra ir erdvinès duomenų bazès informacija.
Trečiajame etape įvardijama Kuršių nerijos nacionalinio parko kultūrinio kraštovaizdžio struktūra ir išskiriamos trys kultūrinio kraštovaizdžio zonos: asociatyvioji, tikslingai suformuota, savaime susiklosčiusi (Feilden, Jokilehto, 1993). Kultūriniame kraštovaizdyje išskiriami probleminiai gamtos ir kultūros paveldo arealai, kurie nustatyti remiantis pirmojo ir antrojo tyrimo etapų rezultatais.

\section{GAMTOS PAVELDO OBJEKTŲ BŪKLE்S VERTINIMAS}

Kuršių nerija i̇ UNESCO pasaulio paveldo sąrašą itraukta remiantis (v) kriterijumi, skirtu kultūros paveldo vietovems identifikuoti. Nerijai taip pat suteiktas kultūrinio kraštovaizdžio statusas, kurio kontekste gamtinè aplinka ir gamtos paveldo objektai atlieka svarbų vaidmeni ir yra neatskiriama jo dalis. Vis dèlto $2000 \mathrm{~m}$. UNESCO ekspertai pateike išvadas, kuriose ịvardijo, kad Kuršių nerijos gamtinè verte pasauliniu lygmeniu yra nepakankama, kad vietové būtų ịtraukta ị Pasaulio paveldo sąrašą kaip mišraus paveldo objektas (24COM XC.1 - Curonian Spit, 2000), tačiau šis faktas nepaneigia gamtos paveldo objektų nacionalinio reikšmingumo lygmens. Kuršių nerijos nacionaliniame parke saugomi gamtos paveldo objektai papildo ir atskleidžia kultūrinị kraštovaizdị,

1 le ntelè. Kultūros paveldo objekto fizinès būklès pokytis (šaltinis: Dèl Kultūros paveldo objekto būklès..., 2005)

Table 1. Changes in the cultural heritage object's physical conditions (Source: Dèl Kultüros paveldo objekto büklés..., 2005)

\begin{tabular}{|c|c|}
\hline $\begin{array}{l}5 \text { - būklè labai } \\
\text { pagerejo / physical condition } \\
\text { greatly improved }\end{array}$ & $\begin{array}{l}\text { Objektas restauruotas, pritaikytas ar atkurtas / The object is restored, adapted or } \\
\text { rebuilt. }\end{array}$ \\
\hline $\begin{array}{l}4 \text { - būklè gerèja / physical con- } \\
\text { dition is improving }\end{array}$ & $\begin{array}{l}\text { ni, restauruojami, atkuriami / Objects that } \\
\text { ed or rebuilt. }\end{array}$ \\
\hline $3-$ & $\begin{array}{l}\text { Objektas yra naudojamas arba nenaudojamas, palaikoma esama objekto būklè, } \\
\text { kuri yra pakankamai gera ir dèl priežiūros neprastèja / The current physical con- } \\
\text { dition of the object is maintained, which is good enough and does not deteriorate } \\
\text { due to maintenance. }\end{array}$ \\
\hline 2 - būklè blogèja / pl & rstate of \\
\hline $\begin{array}{l}1 \text { - būklè labai } \\
\text { pablogèjo / physical condition } \\
\text { greatly deteriorated }\end{array}$ & $\begin{array}{l}\text { Objektas yra sunykęs daugiau kaip } 50 \% \text { arba stipriai nyksta dèl jo nepriežiūros, } \\
\text { objekto aplinkos bükle labai prasta / More than } 50 \% \text { of the object is destroyed, or } \\
\text { its physical condition is deteriorated significantly due to neglect, the environment } \\
\text { of the object is very poor. }\end{array}$ \\
\hline
\end{tabular}


todèl paveldo būklè ir nuolatinè jos stebèsena yra labai svarbi ne tik nacionaliniu, bet ir tarptautiniu mastu.

Nacionaliniu lygmeniu gamtos paveldo apsaugą ir jo būklę reglamentuoja Saugomų teritorijų istatymas, o gamtos paveldo objektų nuostatuose reglamentuojami šių objektų tvarkymo ypatumai (Lietuvos Respublikos saugomu..., 1993; Gamtos paveldo objektu nuostatai, 2005). Saugomų teritorijų ístatyme apibrežiama, kad gamtos paveldo objektai - tai gamtiniai kraštovaizdžio objektai, kuriems teisès aktais yra nustatytas apsaugos ir nau- dojimo režimas (Lietuvos Respublikos saugomų..., 1993). Remiantis Lietuvos Respublikos saugomu teritorijų valstybès kadastro duomenimis, $2017 \mathrm{~m}$. Kuršių nerijos nacionalinio parko teritorijoje buvo iregistruota 11 gamtos paveldo objektų. Parke vyrauja geomorfologiniai paveldo objektai, daugiausia kopos, jų yra aštuonios, taip pat du kyšuliai, yra vienas geologinis objektas - Marių mergelio atodanga (žr. 2 lentelę) (Saugomų teritorijų valstybès kadastras, 2017).

Net 100 \% Kuršių nerijos nacionalinio parko gamtos paveldo objektų yra paskelbti gamtos

2 lentelè. Gamtos paveldo objektų būklè 2009-2011 m. (šaltinis: Veiklos ataskaita, 2009; 2010; 2011)

Table 2. Physical condition of the natural heritage object from 2009 to 2011 (source: Veiklos ataskaita, 2009; 2010; 2011)

\begin{tabular}{|c|c|c|c|c|c|c|c|c|}
\hline \multicolumn{9}{|c|}{ Gamtos paveldo objektai / Natural heritage objects } \\
\hline \multirow{2}{*}{$\begin{array}{l}\text { Nr. } \\
\text { No. }\end{array}$} & \multirow{2}{*}{$\begin{array}{c}\text { Objekto } \\
\text { pavadinimas } \\
\text { Object name }\end{array}$} & \multirow[b]{2}{*}{ Rūšis / Type } & \multirow{2}{*}{$\begin{array}{l}\text { Objektas } \\
\text { Object }\end{array}$} & \multirow{2}{*}{$\begin{array}{l}\text { Gamtos } \\
\text { paminklas } \\
\text { Natural } \\
\text { monument }\end{array}$} & \multicolumn{4}{|c|}{ Būklè / Physical condition } \\
\hline & & & & & 2009 & 2010 & 2011 & 2017 \\
\hline 1. & $\begin{array}{l}\text { Agilos kopa } \\
\text { Dune Agila }\end{array}$ & $\begin{array}{l}\text { Geomorfologinis } \\
\text { Geomorphological }\end{array}$ & $\begin{array}{l}\text { Kopa } \\
\text { Dune }\end{array}$ & $\begin{array}{l}\text { Taip } \\
\text { Yes }\end{array}$ & $\begin{array}{c}\text { Prastèja } \\
\text { Getting } \\
\text { worse }\end{array}$ & $\begin{array}{c}\text { Prastèja } \\
\text { Getting } \\
\text { worse }\end{array}$ & $\begin{array}{c}\text { Prastèja } \\
\text { Getting } \\
\text { worse }\end{array}$ & $\begin{array}{c}\text { Prastèja } \\
\text { Getting } \\
\text { worse }\end{array}$ \\
\hline 2. & $\begin{array}{l}\text { Angiu kalnas } \\
\text { Hill of Adders }\end{array}$ & $\begin{array}{l}\text { Geomorfologinis } \\
\text { Geomorphological }\end{array}$ & & $\begin{array}{l}\text { Taip } \\
\text { Yes }\end{array}$ & $\begin{array}{l}\text { Stabili } \\
\text { Stable }\end{array}$ & $\begin{array}{l}\text { Stabili } \\
\text { Stable }\end{array}$ & $\begin{array}{l}\text { Stabili } \\
\text { Stable }\end{array}$ & $\begin{array}{l}\text { Stabili } \\
\text { Stable }\end{array}$ \\
\hline 3. & $\begin{array}{l}\text { Karvaičiu kopa } \\
\text { Dune Karvaičiai }\end{array}$ & $\begin{array}{l}\text { Geomorfologinis } \\
\text { Geomorphological }\end{array}$ & $\begin{array}{l}\text { Kopa } \\
\text { Dune }\end{array}$ & $\begin{array}{l}\text { Taip } \\
\text { Yes }\end{array}$ & $\begin{array}{l}\text { Stabili } \\
\text { Stable }\end{array}$ & $\begin{array}{l}\text { Stabili } \\
\text { Stable }\end{array}$ & $\begin{array}{l}\text { Stabili } \\
\text { Stable }\end{array}$ & $\begin{array}{l}\text { Stabili } \\
\text { Stable }\end{array}$ \\
\hline 4. & $\begin{array}{l}\text { Lydumo ragas } \\
\text { Lydumas cape }\end{array}$ & $\begin{array}{l}\text { Geomorfologinis } \\
\text { Geomorphological }\end{array}$ & $\begin{array}{l}\text { Kyšulys } \\
\text { Cape }\end{array}$ & $\begin{array}{l}\text { Taip } \\
\text { Yes }\end{array}$ & $\begin{array}{l}\text { Stabili } \\
\text { Stable }\end{array}$ & $\begin{array}{c}\text { Prastèja } \\
\text { Getting } \\
\text { worse }\end{array}$ & $\begin{array}{l}\text { Stabili } \\
\text { Stable }\end{array}$ & $\begin{array}{l}\text { Stabili } \\
\text { Stable }\end{array}$ \\
\hline 5. & $\begin{array}{l}\text { Naglių ragas } \\
\text { Nagliai cape }\end{array}$ & $\begin{array}{l}\text { Geomorfologinis } \\
\text { Geomorphological }\end{array}$ & $\begin{array}{l}\text { Kyšulys } \\
\text { Cape }\end{array}$ & $\begin{array}{l}\text { Taip } \\
\text { Yes }\end{array}$ & $\begin{array}{l}\text { Stabili } \\
\text { Stable }\end{array}$ & $\begin{array}{l}\text { Stabili } \\
\text { Stable }\end{array}$ & $\begin{array}{l}\text { Stabili } \\
\text { Stable }\end{array}$ & $\begin{array}{l}\text { Stabili } \\
\text { Stable }\end{array}$ \\
\hline 6. & $\begin{array}{l}\text { Raganos kalnas } \\
\text { Hill of Witches }\end{array}$ & $\begin{array}{l}\text { Geomorfologinis } \\
\text { Geomorphological }\end{array}$ & $\begin{array}{l}\text { Kopa } \\
\text { Dune }\end{array}$ & $\begin{array}{l}\text { Taip } \\
\text { Yes }\end{array}$ & $\begin{array}{l}\text { Stabili } \\
\text { Stable }\end{array}$ & $\begin{array}{l}\text { Stabili } \\
\text { Stable }\end{array}$ & $\begin{array}{l}\text { Stabili } \\
\text { Stable }\end{array}$ & $\begin{array}{l}\text { Stabili } \\
\text { Stable }\end{array}$ \\
\hline 7. & $\begin{array}{l}\text { Skirspsto kopa } \\
\text { Dune Skirspstas }\end{array}$ & $\begin{array}{l}\text { Geomorfologinis } \\
\text { Geomorphological }\end{array}$ & $\begin{array}{l}\text { Kopa } \\
\text { Dune }\end{array}$ & $\begin{array}{l}\text { Taip } \\
\text { Yes }\end{array}$ & $\begin{array}{l}\text { Stabili } \\
\text { Stable }\end{array}$ & $\begin{array}{l}\text { Stabili } \\
\text { Stable }\end{array}$ & $\begin{array}{l}\text { Stabili } \\
\text { Stable }\end{array}$ & $\begin{array}{l}\text { Stabili } \\
\text { Stable }\end{array}$ \\
\hline 8. & $\begin{array}{l}\text { Urbo kalnas } \\
\text { Urbas hill }\end{array}$ & $\begin{array}{l}\text { Geomorfologinis } \\
\text { Geomorphological }\end{array}$ & $\begin{array}{l}\text { Kopa } \\
\text { Dune }\end{array}$ & $\begin{array}{l}\text { Taip } \\
\text { Yes }\end{array}$ & $\begin{array}{l}\text { Stabili } \\
\text { Stable }\end{array}$ & $\begin{array}{l}\text { Stabili } \\
\text { Stable }\end{array}$ & $\begin{array}{l}\text { Stabili } \\
\text { Stable }\end{array}$ & $\begin{array}{l}\text { Stabili } \\
\text { Stable }\end{array}$ \\
\hline 9. & $\begin{array}{l}\text { Vacekrugo kopa } \\
\text { Dune Vacekrugas }\end{array}$ & $\begin{array}{l}\text { Geomorfologinis } \\
\text { Geomorphological }\end{array}$ & $\begin{array}{l}\text { Kopa } \\
\text { Dune }\end{array}$ & $\begin{array}{l}\text { Taip } \\
\text { Yes }\end{array}$ & $\begin{array}{l}\text { Stabili } \\
\text { Stable }\end{array}$ & $\begin{array}{l}\text { Stabili } \\
\text { Stable }\end{array}$ & $\begin{array}{c}\text { Prastèja } \\
\text { Getting } \\
\text { worse }\end{array}$ & $\begin{array}{l}\text { Stabili } \\
\text { Stable }\end{array}$ \\
\hline 10. & $\begin{array}{l}\text { Vingio kopa } \\
\text { Dune Vingis }\end{array}$ & $\begin{array}{l}\text { Geomorfologinis } \\
\text { Geomorphological }\end{array}$ & $\begin{array}{l}\text { Kopa } \\
\text { Dune }\end{array}$ & $\begin{array}{l}\text { Taip } \\
\text { Yes }\end{array}$ & $\begin{array}{c}\text { Prastèja } \\
\text { Getting } \\
\text { worse }\end{array}$ & $\begin{array}{c}\text { Prastèja } \\
\text { Getting } \\
\text { worse }\end{array}$ & $\begin{array}{c}\text { Prastèja } \\
\text { Getting } \\
\text { worse }\end{array}$ & $\begin{array}{c}\text { Prastèja } \\
\text { Getting } \\
\text { worse }\end{array}$ \\
\hline 11. & $\begin{array}{l}\text { Mariu mergelio } \\
\text { atodanga } \\
\text { Curonian Lagoon } \\
\text { coastal marl outcrop }\end{array}$ & $\begin{array}{l}\text { Geologinis } \\
\text { Geological }\end{array}$ & $\begin{array}{c}\text { Atodanga } \\
\text { Outcrop }\end{array}$ & $\begin{array}{l}\text { Taip } \\
\text { Yes }\end{array}$ & $\begin{array}{l}\text { Stabili } \\
\text { Stable }\end{array}$ & $\begin{array}{l}\text { Stabili } \\
\text { Stable }\end{array}$ & $\begin{array}{l}\text { Stabili } \\
\text { Stable }\end{array}$ & $\begin{array}{l}\text { Stabili } \\
\text { Stable }\end{array}$ \\
\hline
\end{tabular}


paminklais (Saugomu teritoriju valstybès kadastras, 2017). Nepaisnat to, kad nacionalinio parko teritorija užima vos $0,4 \%$ Lietuvos ploto, nerijoje esantys gamtos paminklai sudaro net $7 \%$ visų Lietuvos gamtos paminklų, o geomorfologiniai paminklai - net $36 \%$ visų geomorfologinių paminklų. Tai leidžia daryti išvadą, kad Kuršių nerijos nacionalinio parko gamtos paveldas labai reikšmingas visos Lietuvos gamtos paveldo kontekste, todèl itin svarbu užtikrinti gerą jo būklę. Vienas iš būdų - stebėsenos vykdymas.

Paskutini kartą gamtos paveldo objektų būklè fiksuota natūrinių stebéjimų metu. Oficialūs duomenys atskleidžia, kad tai buvo 2011 metais. Stebejjimus vykdė Kuršių nerijos nacionalinio parko direkcija. Remiantis direkcijos duomeni- mis, $2010 \mathrm{~m}$. buvo pablogèjusi Lydumo rago, o 2011 m. Vacekrugo kopos būklè (žr. 2 lentelę). Pastarųjų objektų padètis laikinai buvo pablogejjusi dèl gamtinių priežasčių. Duomenų apie objektų būklę 2012 m. nèra, o nuo 2013 m. prièmus naują vertinimo metodiką informaciją randame sudarytose KNNP veiklos ataskaitose: 2013 m. pažeistų objektų buvo du, 2014 m. - trys, 2015 m. - pažeistų teritorijų nebuvo, $2016 \mathrm{~m}$. - viena, tačiau dèl atnaujintos vertinimo metodikos lieka neaišku, kurių konkrečiai objektų būklè prastejjo (Veiklos ataskaita, 2013; 2014; 2015; 2016).

Direkcijos ataskaitose pateikti duomenys rodo, kad gamtos paveldo objektų situacija nuolatos kinta, todèl reikalinga nuosekli ir tikslinga jų stebėsena, ịvardijant aiškias būklès blogejjimo

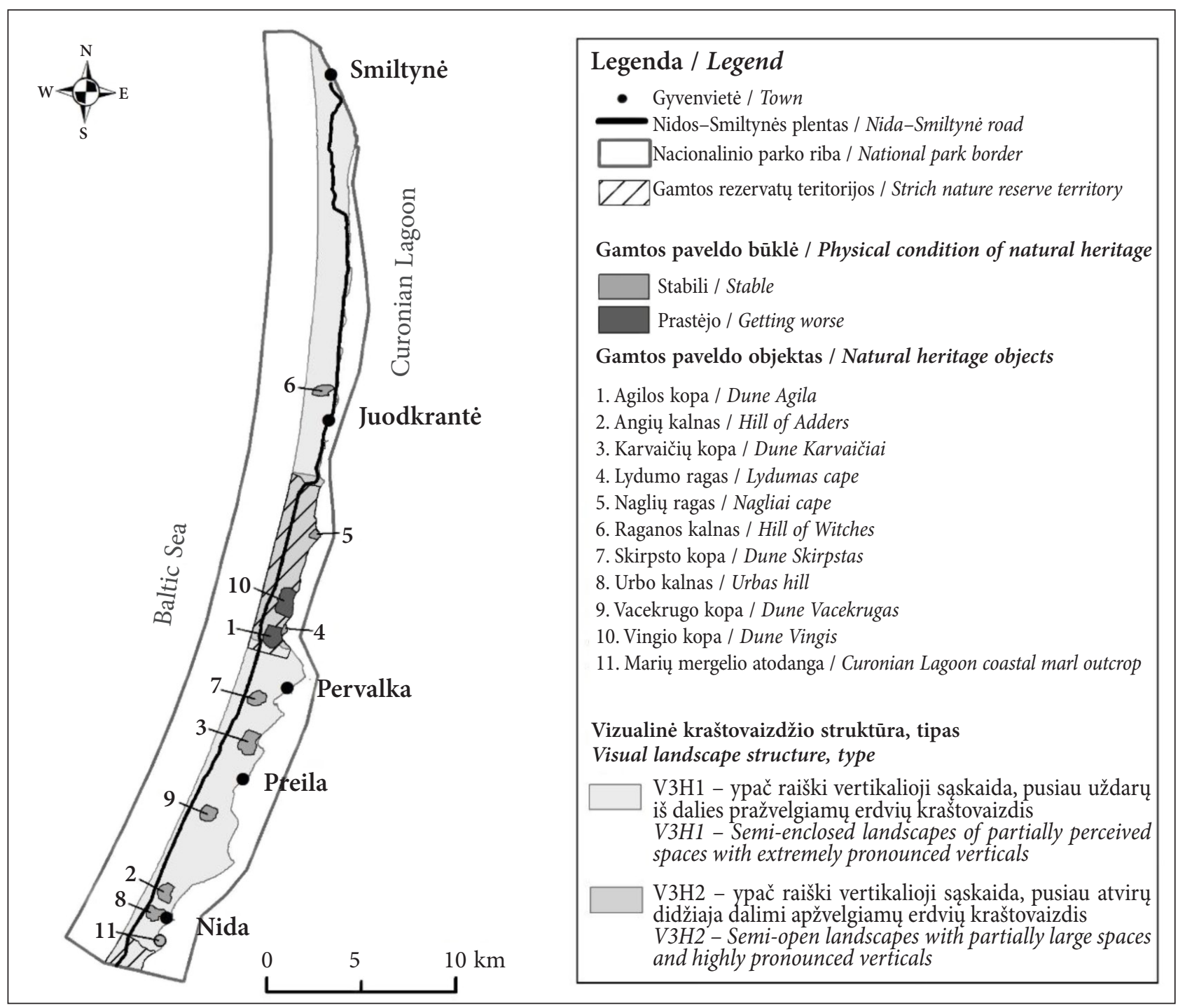

1 pav. Gamtos paveldo objektai ir jų būklè 2009-2011 m. (duomenys: Saugomu teritoriju valstybès kadastras, 2017) Fig. 1. Physical condition of natural heritage objects in 2009-2011 (data: Saugomu teritoriju valstybès kadastras, 2017) 
priežastis (Veiklos ataskaita, 2013; 2014; 2015; 2016). Siekiant išsiaiškinti dabartinę gamtos paveldo būklę, $2017 \mathrm{~m}$. atlikti natūriniai stebejimai. Nustatyta, kad iš vienuolikos nacionaliniame parke esančių gamtos paveldo objektų prastëjo ir iki šių dienų situacija išliko prasta dviejų objektų, esančių Naglių gamtinio rezervato teritorijoje: Agilo ir Vingio kopų (Dèl Kuršiu nerijos nacionalinio..., 2012). Tikètina, kad minètų kopų būkle prasta dèl lankytojų, kurie Naglių rezervato pažintiniame take nesilaiko taisyklių. Remiantis Gamtos tyrimų centro 2015 m. duomenimis, Agilos kopa rezervato pažintinio tako ruože per pastarąji dešimtmeti sumažejo net penkiais metrais (Pažintiniai takai, 2017). Rekreacinès digresijos neigiama ittaka matyti ir šiandien. $2017 \mathrm{~m}$. atliekant stebejimus akivaizdžiai buvo matomi žmonių pèdsakai už atitvarų, o Agilos ir Vingio kopų viršus stipriai nutryptas.

Labai svarbu, kad Agilos ir Vingio kopos patenka ị V3H2 vizualinę kraštovaizdžio zoną, kuri pasižymi itin dideliu estetiniu potencialu. Prastèjanti jų būklè gali neigiamai paveikti bendrą visos Kuršių nerijos kraštovaizdžio estetiką ir sumažinti tarptautinę reikšmę turinčio kultūrinio kraštovaizdžio paveldo vertę.

\section{KULTŪROS PAVELDO OBJEKTAI}

Kuršių nerijos nacionalinis parkas yra pasaulyje pripažintos tarpvalstybinès kultūros paveldo vietovès dalis, pasižymi išskirtinai didele kultūros paveldo objektų gausa. $2000 \mathrm{~m}$. Pasaulio paveldo komitetas, įtraukdamas Kuršių neriją i Pasaulio paveldo sąrašą, ịvardijo tris esmines kultūros paveldo vertybes: žvejų gyvenvietes; gamtos ir (ar) žmogaus sukurtus architektūrinius kūrinius; archeologines vietoves (24COM XC.1 - Curonian Spit, 2000), kurios reprezentuoja paveldo vertę turintị kultūrinị Kuršių nerijos nacionalinio parko kraštovaizdị. Dèl šios priežasties labai svarbu užtikrinti nacionalinio parko teritorijoje esančių kultūros vertybių apsaugą ir būklès stebèseną.

Lietuvoje kultūros paveldo vertybių apsaugą reglamentuoja trys pagrindiniai teisès aktai: Nekilnojamojo kultūros paveldo apsaugos įstatymas, Kilnojamųjų kultūros paveldo vertybių apsaugos isstatymas ir Saugomų teritorijų įstatymas. Tačiau tam, kad būtų išsaugoti objektai ar vietovès kaip vertybès, pirmiausia privalo būti suteikiamas teisinis apsaugos statusas, vertybès privalo būti ịtraukiamos ị kultūros vertybių registrą, o vertingiausiems objektams gali būti suteikiamas kultūros paminklo statusas. Kultūros paveldui taip pat privalo būti nustatytas reikšmingumo lygmuo, kuris gali būti nacionalinis, regioninis ir vietinès reikšmès (Glemža, 2002; Lietuvos Respublikos nekilnojamojo..., 2004 ). Siekiant užtikrinti gerą kultūros paveldo objektų būklę, kiekvienam paveldo objektui ar vietovei privalo būti nustatytas statusas, reikšmingumo lygmuo, vertingosios savybės. Tai labai svarbu siekiant užtikrinti paveldo apsaugą ir priežiūrą.

2017 m. duomenimis, parko teritorijoje įregistruota 217 nekilnojamųjų kultūros paveldo vertybių, iš jų 162 suteiktas valstybès saugomo objekto statusas, 53 objektai turi registrini objekto statusą, du yra paskelbti paminklais (Lietuvos Respublikos kultūros vertybiu registras, 2017). Didžiausią paveldo dali sudaro žvejų ir kt. namai, iš viso jų net $46 \%$ visų paveldo objektų. $17 \%$ visų vertybių yra bažnytinis paveldas ir jam priklausantys objektai: bažnyčios, monstrancijos, klaupkos, religiniai paveikslai. Nemažą paveldo dalị sudaro kapinès, ju dalys, ìskaitant kapus, antkapinius kryžius, antkapius, iš viso $11 \%$ visų objektų. Kurorto statusą primenantis kultūros paveldas: vilos, poilsio namai, viešbučiai apima 9,7 \% paveldo vertybių. Gynybiniai kompleksai ir objektai sudaro $5 \%$ viso kultūros paveldo, o likusieji 11,3 \% - tai kiti paveldo objektai. Dauguma paveldo vertybiu koncentruojasi penkiose gyvenvietėse, urbanistinio paveldo vietovèse: Nidoje, Preiloje, Pervalkoje, Juodkrantèje ir Smiltynèje (Dèl Kuršiu nerijos nacionalinio parko..., 2010).

Visiems paveldo objektams, nepriklausomai nuo jų apsaugos statuso ir rūšies, privalo būti nustatytas reikšmingumo lygmuo. Kuršių nerijos nacionaliniame parke yra vienas vietinès reikšmès, šeši nacionalinès ir 62 regioninès reikšmès objektai. Taigi iš viso reikšmingumo lygmuo nustatytas 69 objektams, tačiau net 148 objektai neturi jokio reikšmingumo lygmens.

Nekilnojamojo kultūros paveldo apsaugos ịstatyme taip pat numatyta, kad visoms be išimties vertybèms privalo būti nustatytos vertingosios savybės, kurios leidžia ịvertinti objektų būklę. Iš viso yra net 13 vertingụjų savybių pobūdžių, kurie irodo objekto ar vietovès paveldo vertę: inžinerinis, dailès, urbanistinis, architektūrinis, 
sakralinis, mitologinis, memorialinis, istorinis, etnokultūrinis, povandeninis, archeologinis, želdynų, kultūrinès raiškos (Lietuvos Respublikos nekilnojamojo..., 2004). Nepaisant kultūros paveldo apsaugos istatyme numatytos tvarkos, šiuo metu iš 217 Kuršių nerijos nacionalinio parko teritorijoje esančių paveldo vertybių vertingosios savybės yra nustatytos tik 73 objektams, tai sudaro 33,6 \% visų objektų. 144 vertybèms nèra nurodyta nei viena savybè, lemianti jos vertingumą, tai sudaro $66,4 \%$ visų nekilnojamojo kultūros paveldo objektų. Reikia paminèti ir tai, kad Nekilnojamojo kultūros paveldo apsaugos įstatyme pagal reikšmingumą lemiančių vertingųjų savybiu pobūdị reglamentuoja tik 13 paveldo rūšiu (Lietuvos Respublikos nekilnojamojo..., 2004), tačiau kultūros vertybių registre yra išskirtas papildomas kraštovaizdžio, kaip vertingosios savybès, pobūdis. Ši savybė nèra ịteisinta paveldo apsaugą reglamentuojančiuose teisès aktuose, tačiau net 16 objektų buvo pripažinti vertingais dèl juos supančio kraštovaizdžio.

Remiantis surinktais ir susistemintais statistiniais duomenimis, Kuršių nerijos nacionaliniame parke dominuoja keturios pagrindinès paveldo grupès: urbanistinio paveldo vietovès, kuriose yra didžiausia kultūros vertybių santalka; architektūrinis paveldas, atspindintis pamario kraštui būdingą architektūros stilių; istorinis paveldas, reprezentuojantis su svarbiais istoriniais ivvkiais susijusias vietas, meno kūrinius, asmenybes, pavyzdžiui, Nidos kopų apželdintojų senųjų kapinių kompleksas; dailès paveldas, daugiausia monumentaliosios dailès kūriniai ir memorialiniai statiniai, kaip Edvikès Pietsch antkapinis kryžius (Lietuvos Respublikos nekilnojamojo..., 2004).

Kuršių nerijos nacionaliniame parke dominuojančios paveldo vertybès puikiai reprezentuoja du iš trijų kultūrinio Kuršių nerijos kraštovaizdžio elementų - žvejų gyvenvietes ir architektūrinį paveldą, tačiau vertybès, įregistruotos ị nekilnojamojo kultūros vertybių registrą, neatskleidžia vieno svarbiausių Kuršių nerijos kultūrinio kraštovaizdžio elementų - archeologinio paveldo. Šiuo metu parko teritorijoje yra registruotos tik dvi archeologinio paveldo vietovès: Nidos senovès gyvenvietė, vadinamoji Penkių kalvelių gyvenvietė (kodas 26019) ir Alksnynès senovès gyvenvietè (kodas 38380) (Kultūros vertybiu registras, 2017). Remiantis svarbiausiu archeolo- ginio paveldo tvarkybą reglamentuojančiu teisès aktu, archeologiniu paveldu laikomi tie objektai, kurie turi vertingų archeologinių savybių bei mena gamybinę arba ūkinę veiklą ar yra buvusi kulto, laidojimo ar gyvenimo vieta (Dèl paveldo tvarkybos..., 2011). Teisès akte taip pat numatoma, kad archeologinès vertybès gali sudaryti archeologini sluoksni, tačiau jame esantys objektai negali būti susidarę vèliau kaip $1800 \mathrm{~m}$. (Dél paveldo tvarkybos..., 2011). Pirmieji Kuršių nerijos kaimai pradèti užpustyti dar 1588 m. (Bučas, 2001), todèl Kuršių nerijos nacionaliniame parke esantys užpustyti kaimai atitinka ne tik archeologinio paveldo, bet ir archeologinio sluoksnio sampratą. UNESCO specialistai dar $2000 \mathrm{~m}$. pripažino, kad užpustyti kaimai yra viena pagrindinių Kuršių nerijos kultūrinio kraštovaizdžio vertinguju savybių, tačiau užpustytiems kaimams teisinis apsaugos statusas iki šiol nèra suteiktas (24COM XC.1 - Curonian Spit, 2000). Lietuva, neittraukdama $\mathfrak{i}$ apskaitą potencialaus archeologinio paveldo vietovių, nesilaiko vienos pagrindinių $1999 \mathrm{~m}$. ratifikuotos $1992 \mathrm{~m}$. Europos archeologijos paveldo apsaugos konvencijos nuostatų ir neužtikrina paveldo išsaugojimo ateities kartoms, nesudaro sąlygų moksliniams tyrimams bei neužtikrina jų būklès (Dèl pataisytos 1992 metų..., 1999).

\section{KULTŪROS PAVELDO OBJEKTŲ BŪKLE்}

Pagal ankstesniame straipsnio skyriuje pateiktus duomenimis, $2017 \mathrm{~m}$. atlikta kultūros paveldo objektų esamos būklès stebèsena, kurios pagrindinis tikslas - išsiaiškinti, kokia yra esama kultūros paveldo objektų būklè, ir nustatyti pagrindines paveldo būklès prastejjimo priežastis. Stebèsenos metu iš viso ịvertinta 142 iš 217 kultūros paveldo objektų. Vertinta statinių - bažnyčių, žveju sodybų, vilų, poilsio namų, ùkinių pastatų, kurie ịtraukti ì registrą, - būklè. Taip pat kapinių kompleksų, senųjų kapinių dalių padètis. Rezultatai buvo lyginami su 2010-2012 m. objektu nuotraukomis, esančiomis kultūros vertybių registre. Vertinamos nebuvo tos kultūros vertybès, kurių koordinatès, adresas ir tiksli buvimo vieta kultūros vertybių registre nèra aiškiai nurodyta. Nebuvo vertintos ir tos kultūros paveldo vertybès, kurių įvertinimas buvo fiziškai neįmanomas, pavyzdžiui, povandeninis paveldas ar mariose esantis Pervalkos švyturys (kodas 21974). 
İvertinus 142 kultūros paveldo objektų būklę paaiškejjo, kad 97 \% stebètų objektų susikoncentravę penkiose urbanistinio paveldo vietovèse: Nidos, Pervalkos, Preilos, Juodkrantès ir Smiltynès gyvenvietèse (žr. 2 pav.), dèl šios priežasties kultūros paveldo objektų esamos būklès ịvertinimo rezultatai perteikti procentine išraiška kiekvienoje gyvenvieteje.

Iš 142 vertybių (100\% visų stebètų objektų) $12 \%$ objektų būklè labai pagerejo; $7 \%$ šiuo metu gereja, vykdomi tvarkybos darbai; $57 \%$ nepakito ir išliko stabili; $21 \%$ blogèjo; $3 \%$ labai pablogejo (žr. 3 lentelę).

Atsižvelgiant $\mathfrak{i}$ tyrimo metu surinktus paveldo objektų ir jų padèties duomenis pagrisstai galima teigti, kad bendra urbanistinių paveldo vietoviu būklè yra nepakitusi. Kita vertus, beveik $18 \%$ Kuršių nerijos nacionalinio parko nekilnojamojo kultūros paveldo objektų situacija yra pablogejjusi, o ankstesniuose skyriuose minètas užpustytas archeologinis paveldas iš viso neturi juridinio statuso. Užpustytų kaimų dabartinè būklè iki šiol yra nežinoma, todèl, tikètina, taip pat yra pablogejusi. Vadinasi, Kuršių nerijos nacionalinio parko teritorijoje esantis nekilnojamasis kultūros paveldas ne visiškai atskleidžia Kuršių nerijos nacionalinị parką ir jo, kaip tarptautinio lygmens saugomos teritorijos, išskirtinumą bei statusą.

I UNESCO pasaulio paveldo sarašą ittrauktose vietovèse esančių paveldo vietovių būklè privalo būti vertinama kiekvienais metais (Dél kultūros paveldo vietoviu..., 2012), o kultūros paveldo objektų būklès stebèsena privalo būti atliekama kas penkerius metus (Dél kultūros paveldo objekto..., 2005). Kuršių nerijos nacionaliniame parke esančių vietovių padèties stebèsena iš tiesų yra



2 pav. Kultūros paveldo būklè Nidos, Preilos, Pervalkos, Juodkrantès ir Smiltynès gyvenvietèse

Fig. 2. Physical condition of cultural heritage in Nida, Preila, Pervalka, Juodkranté, Smiltynè 
3 lentelè. Paveldo objektų būklè urbanistinio paveldo vietovėse: Nidoje, Preiloje, Pervalkoje, Juodkrantëje, Smiltynèje

Table 3. Physical condition of cultural heritage in urban districts: Nida, Preila, Pervalka, Juodkranté, Smiltyne

\begin{tabular}{|c|c|c|c|c|c|c|}
\hline \multirow[b]{2}{*}{$\begin{array}{c}\text { Urbanistinio } \\
\text { paveldo vietovè } \\
\text { District of urban } \\
\text { heritage }\end{array}$} & \multicolumn{5}{|c|}{ Kultūros paveldo objektų būklè / Physical condition of cultural heritage } & \multirow[b]{2}{*}{$\begin{array}{c}\text { Iš viso } \\
\text { paveldo } \\
\text { vertybių } \\
\text { Total } \\
\text { heritage } \\
\text { objects }\end{array}$} \\
\hline & $\begin{array}{c}5 \text { - būklè } \\
\text { labai pagerèjo } \\
\text { physical con- } \\
\text { dition greatly } \\
\text { improved }\end{array}$ & $\begin{array}{l}4 \text { - būklè } \\
\text { pagerèjo } \\
\text { physical } \\
\text { condition } \\
\text { improved }\end{array}$ & $\begin{array}{c}\text { - būklè } \\
\text { nepakito } \\
\text { physical } \\
\text { condition did } \\
\text { not change }\end{array}$ & $\begin{array}{c}2 \text { - būklè } \\
\text { pablogèjo } \\
\text { physical } \\
\text { condition got } \\
\text { deteriorated }\end{array}$ & $\begin{array}{c}1 \text { - būklè } \\
\text { labai pablogèjo } \\
\text { physical condi- } \\
\text { tion greatly } \\
\text { deteriorated }\end{array}$ & \\
\hline Nida & 5 & 7 & 43 & 11 & 1 & 67 \\
\hline Preila & 2 & - & 14 & 6 & 1 & 23 \\
\hline Pervalka & 4 & 1 & 5 & 2 & - & 12 \\
\hline Juodkrantė & 4 & 2 & 16 & 8 & 1 & 31 \\
\hline Smiltynè & 2 & - & 3 & 3 & 1 & 9 \\
\hline Iš viso / Total: & 17 & 10 & 81 & 30 & 4 & 142 \\
\hline $\begin{array}{l}\text { Procentine dalis } \\
\text { (visų ivertintuc } \\
\text { objektų) } \\
\text { Percentage of all } \\
\text { evaluated objects }\end{array}$ & $12 \%$ & $7 \%$ & $57 \%$ & $21 \%$ & $3 \%$ & $100 \%$ \\
\hline
\end{tabular}

vykdoma, o duomenis galima rasti Kultūros paveldo departamento svetainèje. Duomenys apie atskirų paveldo vertybių būklę taip pat privalo būti renkami, todèl dèl duomenų suteikimo raštiškai ir telefonu buvo kreiptasi i Kultūros paveldo departamento Klaipédos skyriaus specialistus, atsakingus už Neringos ir Klaipèdos miesto dalies, esančios nerijoje, kultūros paveldo vertybių būklès stebėseną. Institucija ị raštu pateiktą prašymą neatsakè, o telefonu pateikti minètuosius duomenis atsisakè, todèl abejotina, ar stebèsena iš viso buvo atlikta.

Neringos savivaldybè, kuri atsakinga už kultūros paveldo objektų būklès stebėseną Neringos savivaldybeje, taip pat nepateikè duomenu apie objektų būklę, tik patvirtino, kad tokio pobūdžio duomenys buvo renkami, tačiau jokie kultūros paveldo objekto būklès patikrinimo aktai pildomi nebuvo.

Tiketina, kad Kuršių nerijos nacionalinio parko kultūros paveldo būklè nebuvo stebima nei Neringos, nei Klaipédos miesto daliai priklausančioje parko teritorijoje, taigi neatsakingas institucijų darbas ir nebendradarbiavimas galejo turèti neigiamos įtakos Kuršių nerijos nacionalinio parko, kaip vientisos teritorijos, kultūros paveldo būklei.

\section{KULTŪRINIS KURŠIŲ NERIJOS KRAŠTOVAIZDIS}

2000 m. Kuršių nerijos nacionalinis parkas tapo ne tik tarptautinio lygmens saugoma kultūros paveldo vietové, bet buvo priskirtas vienai iš specifinių paveldo kategorijų - kultūriniam kraštovaizdžiui. Kultūriniais kraštovaizdžiais laikomos tos vietos, kurias kartu sukūrè žmogus ir gamta. Remiantis UNESCO paveldo konvencijos 1 straipsniu, šios vietos „atspindi visuomenès evoliuciją ir žmoniu kūrimąsi tam tikroje aplinkoje, kovą su fizinèmis kliūtimis ir (arba) gebejjimą pasinaudoti natūralios aplinkos teikiamais pranašumais bei socialinèmis, ekonominèmis ir kultūrinèmis - tiek vidinėmis, tiek išorinèmis - sąlygomis" (Pasaulio paveldo konvencijos..., 2006).

Pagal UNESCO, kiekviename kultūriniame kraštovaizdyje privalo būti išskirtos trys kultūrinio kraštovaizdžio zonos:

- tikslingai žmogaus pagalba sukurti ir suprojektuoti kraštovaizdžiai;

- savaime susiklostęs kraštovaizdis, nulemtas socialinių-ekonominių, administracinių ir (ar) religinių veiksnių;

- asociatyvus kraštovaizdis, vertingas dèl kultūrinių dvasinių, religinių, meninių sąsajų, 
susijusių su gamtiniais elementais (Feilden, Jokilehto, 1993).

Siekiant atskleisti Kuršiu nerijos kraštovaizdžio paveldo vertę, žmogaus sukurto, savaime susiklosčiusio ir asociatyvaus kraštovaizdžio kategorijos buvo išskirtos Neringos savivaldybès teritorijos bendrojo plano bendrojoje kultūros paveldo tvarkymo ir apsaugos sistemos dalyje (Bendroji kultūros paveldo..., 2012).

Vis dèlto tam, kad būtų išlaikyta gera paveldo vertę turinčio kultūrinio Kuršių nerijos nacionalinio parko kraštovaizdžio būklè, nepakanka vien išskirti minètas zonas, labai svarbu įvertin- ti esamą kultūrinio kraštovaizdžio būklę, kuri tiesiogiai priklauso nuo jame esančiu gamtos ir kultūros paveldo objektų situacijos. Atsižvelgiant i anksčiau pateiktus tyrimo rezultatus, Kuršiu nerijos nacionaliniame parke buvo išskirtos trys probleminès paveldo sritys (3 pav.).

Paveiksle pažymėta viena probleminé gamtos paveldo sritis, esanti ties Agilos ir Vingio kopomis. Ši sritis buvo išskirta remiantis ankstesnèse straipsnio dalyse aprašytais tyrimo rezultatais. Probleminè gamtos paveldo sritis patenka i ypač didelio estetinio potencialo asociatyvaus kultūrinio kraštovaizdžio zoną, todèl gamtos



3 pav. Kultūrinio kraštovaizdžio struktūra ir probleminiai paveldo arealai (duomenys: Bendroji kultūros paveldo..., 2012)

Fig. 3. Cultural landscape structure and problematic heritage areas (data: Bendroji kultūros paveldo..., 2012) 
paveldo būklès prastèjimas minètoje kultūrinio kraštovaizdžio zonoje lemia nacionalinio parko teritorijos, kaip kultūros paveldo vietovès, vertès ir vizualinio kraštovaizdžio patrauklumo mažèjimą.

Remiantis natūrinès stebėsenos metu surinktais duomenimis, išskirtos probleminès kultūros paveldo sritys. Urbanistinio paveldo vietovès, kuriose koncentruojasi didžioji dauguma nekilnojamojo kultūros paveldo, buvo įvertintos procentais. Gyvenvietès, kuriose daugiau kaip $30 \%$ paveldo objektų būklè pablogejo per pastaruosius 10-15 metų, priskirtos probleminèms kultūros paveldo sritims. Iš viso išskirtos dvi sritys: ties Smiltyne ir Preila. Probleminès kultūros paveldo sritys patenka $\mathfrak{i}$ tikslingai žmogaus suformuoto kultūrinio kraštovaizdžio teritoriją, kuri apima tokius kultūrinius kraštovaizdžio elementus kaip gyvenvietes su jose esančiais pastatais ir žmonių atsodintais miškais.

Kultūros paveldo objektų būklès prastẻjimas šiose srityse - tai unikalaus, tikslingai žmogaus sukurto, pamario kraštui būdingo kultūros paveldo nykimas, todèl paveldo būklès prastëjimas šiose srityse daro neigiamą ittaką gyvenamųjų zonų estetinei vertei ir šiose zonose gyvenančių žmonių kultūriniam identitetui.

Nors Kuršių nerijos nacionalinio parko kultūriniame kraštovaizdyje buvo išskirti trys lokalūs probleminiai arealai, atsižvelgiant $\mathfrak{i}$ tai, kad didesnių gamtos ir kultūros paveldo probleminių arealų per tyrimą nebuvo pastebèta, Kuršių nerijos kultūrinio kraštovaizdžio bendrą būklę šiuo metu būtų galima vertinti teigimai.

\section{IŠVADOS}

1. Kuršių nerija yra tapusi įvairių sričių mokslininku tyrimu objektu. Daugiausia nerija tirta ivairiais gamtiniais, kur kas mažiau analizuota visuomeniniais aspektais, o kompleksinio pobūdžio tyrimų, kuriuose būtų vertinama šios teritorijos paveldo būklè atsižvelgiant ì gamtos, kultūros paveldo objektų ir kultūrinio kraštovaizdžio situaciją, iš viso nèra. Kuršių nerijos nacionalinis parkas yra kompleksinio pobūdžio saugoma teritorija, turinti ne tik nacionalini, bet ir tarptautini apsaugos statusą, kompleksiniai paveldo tyrimai šioje teritorijoje - būtinybè.
2. Dèl rekreacinès digresijos didžiausią kraštovaizdžio vizualinę vertę turinčioje Kuršių nerijos nacionalinio parko dalyje esančiu gamtos paminklų Agilos ir Vingio kopų būklè nuolatos blogejja, mažèja asociatyvaus kultūrinio kraštovaizdžio vertè, todèl būtina imtis griežtesnių ekonominių ir apsaugos priemonių gamtos paveldui išsaugoti.

3. Kuršių nerija pasižymi ypač didele kultūros paveldo gausa, tačiau ne visoms kultūros paveldo vertybėms, pavyzdžiui, užpustytiems kaimams, yra suteiktas teisinis statusas, o apie $18 \%$ itteisintų vertybių būklè šiuo metu yra pablogejjusi. Tai trukdo visapusiškai atskleisti Kuršių nerijos, kaip nacionalinio parko ir Pasaulio kultūros paveldo vietovès, statusą. Ateityje kultūros paveldo sąrašas turètų būti pildomas.

4. Norint užtikrinti gerą Kuršių nerijos nacionalinio parko kultūrinio kraštovaizdžio būklę, didžiausias dèmesys turètų būti skiriamas asociatyviajai ir tikslingai suformuotai Kuršių nerijos kultūrinio kraštovaizdžio zonoms, kurių būklè gali pablogèti dèl nuosekliai nevykdomos gamtos ir kultūros paveldo objektų būklès stebèsenos.

5. Nuolatinè paveldo būklès stebèsena padeda laiku identifikuoti paveldo padèties prastėjimą lemiančias priežastis ir imtis atitinkamų priemonių. Kad Kuršių nerijos nacionalinio parko paveldo būklè gerètų, pirmiausia turi būti užtikrintas bendradarbiavimas tarp padètị vertinančių institucijų.

Gauta 20180201

Priimta 20180302

\section{ŠALTINIAI IR LITERATŪRA}

1. Aukštaitis J. 1996. Lietuvos nacionaliniai parkai. Vilnius: Margi raštai.

2. Bandžiulienè R., Kazlauskas R., Minkevičius V. 1983. Kušiu nerija. Vilnius: Mokslas.

3. Braškytè L. 2017. Kuršiu nerijos nacionalinio parko paveldo būklès vertinimas: bakalauro darbas. Vilnius: VU.

4. Bučas J. 2001. Kuršiu nerijos nacionalinis parkas. Vilnius: Savastis.

5. Feilden B. M., Jokilehto J. 1998. Management Guidelines for World Cultural Heritage Sites. ICCROM.

6. Gamtos paveldo objektu nuostatai. Žin., 2005, Nr. D1-214.

7. Glemža J. R. 2002. Nekilnojamojo kultūros paveldo apsauga ir tvarkymas: paveldosaugos ir paveldotvarkos pagrindai. Vilnius: Vilniaus dailès akademijos leidykla. 
8. Gudelis V. 1960. Kuršiu nerija ir marios. Vilnius: Valstybinè politinès ir mokslinès literatūros leidykla.

9. Gudelis V. 1970. Kuršiu nerija. Vilnius: Mintis.

10. Gudelis V. 1997. Retrospective view on the interaction between nature and man in the Curonian Lagoon (Kuršių nerija). Geografijos metraštis. 30: 28-30.

11. Kristapavičius H. 1957. Užpustyti Kuršių nerijos kaimai. Mokslas ir gyvenimas. 3.

12. Kuršių nerijos nacionalinio parko direkcija. 2009. Veiklos ataskaita $2009 \mathrm{~m}$. Neringa.

13. Kuršių nerijos nacionalinio parko direkcija. 2010. Veiklos ataskaita $2010 \mathrm{~m}$. Neringa.

14. Kuršių nerijos nacionalinio parko direkcija. 2011. Veiklos ataskaita $2011 \mathrm{~m}$. Neringa.

15. Kuršių nerijos nacionalinio parko direkcija. 2013. Veiklos ataskaita 2013 m. Neringa.

16. Kuršių nerijos nacionalinio parko direkcija. 2014. Veiklos ataskaita $2014 \mathrm{~m}$. Neringa.

17. Kuršių nerijos nacionalinio parko direkcija. 2015. Veiklos ataskaita $2015 \mathrm{~m}$. Neringa.

18. Kuršių nerijos nacionalinio parko direkcija. 2016. Veiklos ataskaita $2016 \mathrm{~m}$. Neringa.

19. Lietuvos kraštovaizdžio etnokultūrinis rajonavimas: Lietuvos nacionalinis atlasas. 2008. Vilnius: Nacionalinè žemès tarnyba. M 1: 2000000.

20. Lietuvos Respublikos kultūros vertybiu registras. 2017. https://kvr.kpd.lt/\#/static-heritage-search [žiūrèta 20170405 ].

21. Lietuvos Respublikos nekilnojamojo kultūros paveldo apsaugos istatymas. Žin., 2004, Nr. 153-5571.

22. Lietuvos Respublikos saugomu teritoriju istatymas. Žin., 1993, Nr. 63-1188; 2001, Nr. 1083902.

23. Lietuvos Respublikos saugomu teritoriju valstybès kadastras. 2017. https://stk.am.lt/portal/ [žiūrèta 201704 05].
24. Lietuvos Respublikos Seimo įstatymas „Dèl pataisytos 1992 metu Europos archeologijos paveldo apsaugos konvencijos ratifikavimo“. Žin., 1999. Nr. 1002890.

25. Lietuvos Respublikos Seimo nutarimas „Dèl Kuršiu nerijos nacionalinio parko ir jo zonu ribu plano patvirtinimo“. Žin., 2010, Nr. 153-7802.

26. Lietuvos Respublikos Vyriausybès nutarimas „Dèl Kuršiu nerijos nacionalinio parko tvarkymo plano patvirtinimo“. Žin., 2012, Nr. 70-0.

27. LR kultūros ministro įsakymas „Dèl kultūros paveldo objekto būkles tikrinimo taisykliu patvirtinimo“. Žin., 2005, Nr. IV-199.

28. LR kultūros ministro įsakymas „Dèl kultūros paveldo vietoviu stebesenos taisykliu patirtinimo“. Žin., 2012, Nr. IV-94.

29. Meškys J. 1957. Kuršių neringa. Vilnius: Valstybinẻ politinès ir mokslinès literatūros leidykla.

30. Neringos savivaldybès taryba. 2012. Bendroji kultūros paveldo tvarkymo ir apsaugos sistema. Kaunas: KTU Architektūros ir statybos institutas. M 1:25000.

31. Lietuvos Respublikos kultūros ministro isakymas „Dél paveldo tvarkybos reglamento PTR 2.13.01:2011 „archeologinio paveldo tvarkyba“ patvirtinimo“. Žin., 2011, Nr. IV-538.

32. Pažintiniai takai. http://www.nerija.lt [žiūrèta 201705 01].

33. Telksnytė M. 1979. Kuršiu nerija. Vilnius: Mintis.

34. UNESCO World Heritage Centre. Pasaulio paveldo konvencijos igyvendinimo gairés. 2006. Vilnius: Lietuvos nacionalinè UNESCO komisija.

35. 24COM XC.1 - Curonian Spit (Lithuania / Russian Federation). UNESCO. 2000. Cairns, WHC-2000/ CONF.204/21. 
Ligita Braškytė, Regina Prapiestienė

\section{EVALUATION OF THE CURONIAN SPIT NATIONAL PARK HERITAGE CONDITION}

\section{Sum mary}

The major purpose of the work is to contribute to the combined cultural landscape heritage research. The condition of an object of heritage is one of the most important criteria in heritage research. It is very important to assess the condition of heritage in protected areas like national and regional parks to ensure effective safeguard of natural and cultural heritage.

Nevertheless, the analysis of literature revealed that studies of the combined natural and cultural heritage in Lithuania are still a new field, but it does not deny that combined studies of heritage are very important in a theoretical aspect: collecting data about individual objects of heritage, and in practical terms: forming priority directions of heritage management or making proposals for adjustments to the boundaries of protected areas' management plan zones.

The Curonian Spit National Park heritage leads to the national and outstanding universal value of the park. To make sure effective measures are taken for the protection, conservation and presentation of the cultural and natural heritage, monitoring should be a priority.
The results of combined heritage research of the $\mathrm{Cu}$ ronian Spit National Park discussed in this article and the assessment of the condition of heritage were based on data collected in 2017. The research focused on two aspects: the Curonian Spit cultural landscape is recognized as global cultural heritage and the Curonian Spit National Park has many objects of natural and cultural heritage recognised as national heritage. The research has shown one natural heritage problem area, located between Agilos and Vingio dunes, and two cultural heritage problem areas - Smiltyne and Pervalka urban reserves. The problem heritage areas are in the associative cultural landscape zone and a clearly defined landscape zone (confirmed by UNESCO) which leads to a decrease in the visual potential of the cultural landscape.

Mass recreation, visual pollution, lack of specialists, research, funds and inter-institutional cooperation are the main reasons causing the degradation of natural and cultural heritage as well as cultural landscape degradation in the Curonian Spit National Park. Due to this reason, the combined heritage research is essential in defining the main heritage problems, as well as helping to identify the solutions to these problems.

Keywords: natural heritage, cultural heritage, cultural landscape, physical condition 